\title{
Türkiye Ekonomisinde Hükümetlerin Ekonomik Performanslarının TOPSIS Yöntemi İle Ölçülmesi
}

Selim SANLISOY, Department of Economics, Faculty of Economics and Administrative Sciences, Dokuz Eylul University, Turkey; e-mail: selim.sanlisoy@deu.edu.tr

Mehmet ÇETIN, Department of Economics, Faculty of Economics and Administrative Sciences, Dokuz Eylul University, Turkey; e-mail:mehmet.cetin@deu.edu.tr

\section{The Evaluation of Economic Performances of Governments in Turkish Economy with TOPSIS Method ${ }^{2}$}

\begin{abstract}
Economic performance is a rate of success that ensues as a result of the employment of demographic and economic sources according to a certain coordination for the objectives intended to be achieved. Measuring the government performance is decisive for the efficiency of public sector as it is important for the government to persist its position. In this study, the economic performances of the governments for the period between the years 1950 and 2015 were compared using the TOPSIS (Technique for Order Preference by Similarity to Ideal Solution) method in the Turkish economy. The indicators which were preferred as criterias are related with the economic process policy objectives to determine the government performances. Findings show that single party governments have performed better than the coalition governments and the period of transition to the open economy is the most successful above all.
\end{abstract}

Keywords

Government Performance, Multiple Criteria Decision Making Method, Administrative and Periodical Comparison.

JEL Classification Codes : $\quad$ D70, D81, H1.

$$
\text { Öz }
$$

Ekonomik performans, beşerî ve iktisadî kaynakların, ulaşılması amaçlanan hedeflere yönelik olarak belirli bir koordinasyon çerçevesinde kullanılması sonucunda ortaya çıkan başarı oranıdır. Hükümet performansının ölçülmesi kamu sektörünün etkinliği açısından belirleyici olduğu

I Bu çalışma Başbakanlık Atatürk Kültür, Dil ve Tarih Yüksek Kurumu Atatürk Araştırma Merkezi Başkanlığl ve Dokuz Eylül Üniversitesi Atatürk İlkeleri ve İnklap Tarihi Enstitüsü, "Türkiye Cumhuriyeti'nin Ekonomik ve Sosyal Tarihi Uluslararası Sempozyumu” 26-28 Kasım 2015, sempozyumunda bildiri olarak sunulmuştur.

2 This study has been presented in the symposium entitled "The International Symposium on the Economic and Social History of the Republic of Turkey" which was held with the collaboration of Ataturk Supreme Council for Culture, Language and History - Ataturk Research Center and the Presidency of Dokuz Eylul University Principles of Ataturk and Revolution History Institute in Izmir on 26-28 November 2015. 
kadar söz konusu hükümetin varlığını sürdürebilmesi açısından da önemlidir. Bu çalışmada TOPSIS (Technique for Order Preference by Similarity to Ideal Solution) yöntemi kullanılarak Türkiye Ekonomisi'nde 1950 - 2015 dönemi için hükümetlerin ekonomik performansları karşılaştırılmıştır. Hükümet performanslarının belirlenmesinde kriter olarak ekonomik süreç politikası amaçları ile bağlantılı göstergeler seçilmiştir. Elde edilen bulgular tek parti iktidarlarının koalisyon hükümetlerine göre daha yüksek bir performans sergilediğini ortaya koymakla birlikte dışa açık ekonomiye geçiş döneminin en başarılı dönem olduğunu göstermektedir.

Anahtar Sözcükler $\quad$ : Hükümet Performans1, Çok Kriterli Karar Verme Yöntemleri, Dönemsel ve Yönetsel Karşılaştırma.

\section{Giriş}

Beşeri ve iktisadi kaynakların ulaşılması amaçlanan hedeflere yönelik olarak belirli bir kombinasyon çerçevesinde istihdam edilmesi sonucunda ortaya çıkan başarı ekonomik performans olarak adlandırılır. Ekonomik süreç politikası, üretici ve tüketici kararlarının etkilenmesiyle ekonomik alandaki hedeflerin gerçekleştirilmesini amaçlamaktadır. Bu çerçevede büyüme, istihdam, fiyat istikrarı, faiz oranı, kamu borcu, cari açık ve bütçe açığına ilişkin hedefler bir bütün halinde refah ve sosyal hasılanın maksimizasyonu amacını oluşturmaktadır. Amaçların öncelik sırası ise toplumun değer yargıları, ideolojiler, sosyal grupların ekonomik çıkarları ve mevcut ekonomik durumun amaçlardan sapma derecesi tarafindan belirlenmektedir (Erkan, 2000: 20,156). Politik istikrarsızlık, ekonomik süreç politikasının amaçlarının tümünü etkileyebilmektedir. $\mathrm{Bu}$ nedenle ekonomik gelişme için politik rejimden ziyade politik istikrar ön plana çıkmaktadır. Dolayısıyla siyasi partilerin ekonomik alandaki başarı ve istikrarı performanslarının ölçülmesi açısından politik eğilimlerine göre daha belirleyicidir.

Türk siyasi rejimi temelde üç dönemden geçmiştir. Birinci dönem, siyasi partiler, meşrutiyet ve parlamento kavramlarının Osmanlı siyasi hayatına girdiği ve Jön Türkleri de içerisine alan dönemdir. İkinci dönem 1945 yılında Demokrat Parti’nin kuruluşuna kadar geçen tek parti idaresini kapsar. Bu dönemde demokrasinin toplumsal ve ekonomik temelleri hazırlanmıştır. 1946 yılı ile başlayan üçüncü dönem ise gerçek demokratik temeller üzerine oturtulmuş çok partili bir siyasal rejimi hedeflemektedir (Karpat, 2010: 527-528). Bu bakımdan ilk demokratik seçimlerin 1950 yılında gerçekleştirildiği dikkate alındığında Türkiye altmış beş yıllık bir demokratik geleneğe sahiptir. Yarım yüzyıldan daha uzun olan bu zaman zarfı, dış ve iç politik dönüşümlerle paralel bir biçimde gerçekleşen ekonomik dönüşüm, darbe ve krizlere bağlı olarak yaşanan kırılmalarla karakterize edilmiştir. Bu bakımdan her hükümet dönemi kendi içerisinde ve kendine has eko-politik özellikleri ile ele alınabilmektedir. Aynı hükümet döneminde dahi kendine özgü özelliklere sahip farklı alt dönemler ortaya çıkabilmektedir.

Türk demokrasi tarihi için bu durumun en açık örneği Demokrat Parti (DP) dönemi olmuştur. 1950-1960 arası döneme hâkim olan Demokrat Parti iktidarı, 1945 yılı ile tedricen sona ermeye başlayan Milli Şef döneminin ardından uluslararası politikada ortaya çıkan yeni güç dengesinin iç politikadaki yansıması olarak otoriter tek partili rejimlere karşı 
liberal demokrasinin kazandığı zaferin bir sonucuydu. İktisadi alanda ise izlenen ekonomi politikası Cumhuriyet' in kuruluşundan itibaren uygulanan devletin yardımıyla özel girişimi geliştirme stratejisinin devamı niteliğindeydi. Ancak 1930'lu yılların devlet işletmeciliği yerine dolaylı devlet desteği ön plandaydı (Koçak, 1997: 134,180). Kore Savaşı'nın neden olduğu dış talep, II. Dünya Savaşı sonrası Batı'da gelişen devlet güdümlü ekonomilerin aksine tarımsal gelişme odaklı özel girişimciliği destekleyen DP iktidarı için yüksek büyüme oranlarının yakalanmasına imkân vermiştir. Kore Savaşı'nın sona ermesi ve kötü iklim koşulları durumu tersine çevirmiştir (www.tbmm.gov.tr). 1950-54 döneminde liberal iktisadi politikalar izleyen ve bu söylemlerle iktidara gelen DP, 1954 yılı ile birlikte liberal iktisadi politikalardan vazgeçerek devletçi kontrol tedbirlerinden bazılarını yeniden benimsemiştir. Serbest piyasa idealinden uzaklaşmaya başlayan DP, bunun yerine tipik popülist bir biçimde enflasyon yolu ile olası bir krizi ertelemeyi amaçlayan bir iktisadi politikayı uygulamaya başlamıştır (Keyder, 2008: 160,167). Bu dönemde milli gelirin büyüme hızı kendisinden önceki ve sonraki dönemler ile kıyaslandığında belirgin bir biçimde düşüktür. Ekonomi dış kaynak bağımlı bir büyüme patikasına girmiştir. Dolayısıyla dış kaynak girişinde yaşanan her tıkanma büyüme hızını kendiliğinden aşağıya çekmiştir (Boratav, 2005: 111). Nitekim 1958 iktisadi bunalımının çözümsüzlüğü karşısında hükümet, dış kaynak sağlayabilmek adına IMF ve Dünya Bankası'nın dayatmalarını kabul etmek zorunda kalmıştır (Akşin, 2000: 128). Dönem içerisinde yaşanan ekonomik bunalım ve DP iktidarının muhalif kesimlere yönelik türlü baskıları, politik istikrarsızlığı ve askeri müdahaleyi ortaya çıkarmıştır.

1960 sonrası dönemin en belirleyici özelliklerinden birisi askerlerin siyasete sık sık doğrudan müdahale etmeleridir. Ordu, 1960 Darbesi ile siyasi arenadaki yerini alırken 1961, 1966, 1973, 1980 seçimlerinde ve kısmen de 28 Şubat 1997 ve 27 Nisan 2007 postmodern darbe ve muhtıralarında olduğu gibi rejimin dayanak noktalarını elinde tutmaya çalışmıştır. Bununla birlikte 1960'ların başından yaşanılan dönüşüm ve OYAK'ın oluşturulması ile ordu, ekonomide de yerini almış ve kurum olarak ticaret yapma imkânına da erişmiştir. Buna karşın Türk Ordusu başka ülkelerdeki müdahalelerin aksine politikanın orduya girmesinin yaratabileceği olumsuz etkilerden dolayı kendi yönetimlerini güçlendirmek yerine sona erdirmeyi yeğlemiştir (Özdemir, 1997: 191-192,201; Lewis, 2007: 28). Bu dönemde siyasi alanda birincisi Jön Türkler-İttihat ve Terakki-Müdafaa-y1 Hukuk-CHP yolunun sürdürülerek köktenci reformlar yapabilecek tek parti yönetimi ile Prens Sabahattin-Hürriyet ve İtilaf-Terakkiperver Cumhuriyet Firkası-DP yolunun sürdürülerek muhafazakâr partilerin yönetimde olduğu bir rejimi amaçlayan iki farklı siyasi akım bulunmaktadır. Ekonomik alanda önemli bir güç olan devlet işletmeleri, birinci akımı temsil eden kesimlerce devletçilik şeklinde formüle edilecek olan kapitalist olmayan bir kalkınma modelinin işletilmesini sağlamıştır. Bu amaçla DPT kurularak 15 yıl içinde gerçekleşmesi istenen ekonomik ve toplumsal amaçlar ile bunlara uygun araçlar ve bu araçların kullanılmasında uyulacak temel ilkeleri gösteren "Plan Hedef ve Stratejisi" esas alınarak, 15 yıllık bir perspektif plan hazırlanmıştır. Böylece ekonominin yatırım politikaları ile belirlenen uzun dönemli kaynak tahsisatı büyük ölçüde plan hedeflerine bağlı olarak belirlenmiştir (Koçak, 1997: 212; Özateşler, 1998: 80; Boratav, 2005: 118). 
1960-1980 döneminin en belirgin özelliği iç piyasaya dönük, ithal ikameci sanayileşme stratejisinin kalkınma planları çerçevesinde sürdürülmesi ve bu doğrultuda koruyucu dış ticaret politikası, sıkı kambiyo denetimi ve devlet müdahalesi eşliğinde selektif maliye ve para politikalarının uygulanması olmuştur (Şanlısoy, 2007: 205). 1962-65 yılları arasındaki CHP iktidarındaki politik olarak istikrarsız olarak nitelendirilebilecek kısa süreli dört koalisyon hükümetinin ardından tek başına iktidarı ele alan AP, 1971 yılına kadar devam eden süreçte ABD ile SSCB ilişkilerinin yumuşamasının etkisiyle oluşan olumlu uluslararası konjonktürden faydalanmasını bilmiş ve yurtdışından gelen işçi dövizleri ile birlikte iktisadi büyümenin hızlanmasını sağlayabilmiştir. Buna karşın 1970'lere doğru dünya genelinde yaşanan ekonomik bunalım, Türkiye ekonomisinin ithalata bağımlı iktisadi yapısından kaynaklanan tıkanıklıkla birleşmiş ve ortaya çıkan bunalım, emekçi halk kesimlerinde yaşanan rahatsızlık ve 1960'lı yılların sonunda meydana gelen öğrenci hareketleri ile birlikte ekonomik ve politik istikrarsızlığa neden olmuştur (Koçak, 1997: 217 218). Yaşanan toplumsal ve iktisadi sorunlardan 1961 Anayasası'nı sorumlu tutan 1971 muhtırası ile 1973 seçimlerine kadar görev yapacak geçici hükümetler meydana getirilmişse de politik istikrarsızlığın önüne geçilememiştir. Bu hükümetlerden I. Erim hükümeti 8,5 ay, II. Erim hükümeti 4 ay ve Ferit Melen hükümeti ise 11 ay görevde kalmıştır.

1970-80 döneminin temel olaylarını, 1973 Dünya Petrol Krizi, 1974 Kıbrıs Barış Harekâtı, 24 Ocak 1980 Kararları ve 12 Eylül Darbesi oluşturmaktadır. Kurulan geçici hükümetlerin ardından 1970'lerin ortalarında şiddetlenen siyasi rekabet, CHP-MSP ve Milliyetçi Cephe koalisyonları gibi çok sayıda partiden meydana gelen istikrarsız yönetimlerle sonuçlanmıştır. Kurulan hükümetlerin ekonomiyle ilgili radikal tedbirler almakta gösterdikleri popülist çekinceler döviz bolluğuna bağlı sistemin devamlılı̆̆ını tehlikeye atmıştır. Kıbrıs Barış Harekâtı neticesinde ve Petrol Krizi'ne de bağlı olarak Batılı devletler ve ABD'nin Türkiye’ye yaptıkları resmi yardımları kesmeleri, dış dinamiklere karşı savunmasız ve başarısı tümüyle genişleyen dünya pazarlarına ve ucuz petrole bağlı olan Türkiye ekonomisinin mevcut modelinin sonunu getirmiştir (Keyder, 2008: 227-233). Bununla birlikte artan siyasi istikrarsızlık ve partiler arası çekişmenin şiddetlenmesi biçiminde kendisini gösteren politik güçlüklerin yaratılan yapay bir refah konjonktürü ile aşılmaya çalışılmasına dayanan Demirel çizgisinin başarısızlığa uğraması kaçınılmaz olmuştur. Yaşanan iktisadi sorunlara paralel bir biçimde 1970'li yılların sonuna doğru Türkiye'de farklı gruplar arasındaki gerginlikler artmış, Malatya ve Kahramanmaraş olayları yaşanmış, bu durum da politik istikrarsızlığ 1 derinleştirmiştir (Şanlısoy, 2007: 203; Boratav, 2005: 129).

Ekonominin yeniden işler hale getirilmesi için alınan 24 Ocak 1980 ekonomik istikrar ve yapısal uyum programı ve ardından 12 Eylül 1980 Askeri Müdahalesi, Türkiye'de yeni bir dönemi başlatmıştır (Koçak, 1997: 246). 24 Ocak Kararları, ithal ikameci sanayileşme stratejisinden ihracata yönelik sanayileşme stratejisine geçişin ilk adımını oluşturmaktadır. Karma ekonomik sistem yerini daha liberal bir anlayışa bırakmış ve modern ekonomi politikası araçlarının ağırlık kazandığı bir dönem açılmıştır. Krizi takiben Türkiye'de uygulanan programların biçimlendirdiği 1980-1990 dönemi, sermaye akışında ve döviz üzerinde denetim, düzenleme ve teşviklerle desteklenen bir ihracat yönelimi, reel 
ücretlerin ciddi bir biçimde bastırılması ve ticari serbestleşme ile karakterize edilebilir (Sönmez, 2003: 322; Güngen, 2006: 69-70). 1980 sonrası reform süreci 1988 y1lına gelindiğinde hızını kaybetmiş ve ekonomi bir tıkanma içine girmiştir. Bu durum, ihracata yönelik büyüme politikalarının iktisadi ve sosyal sınırlarına ulaşıldığını göstermektedir. Bunu izleyen yıllarda artık Türkiye ekonomisinde dışa açılım öncelikleri reel üretim sektörlerinde değil; finans ve kambiyo hizmetlerini de kapsayacak politika değişiklikleriyle biçimlenmiştir (Yeldan, 2001: 39). Politik süreç ise başkanlığını Orgeneral Kenan Evren'in yaptığı Milli Güvenlik Konseyi'nin 24 Nisan 1983 tarihinde politik faaliyetleri serbest bırakması ile başlamış; 6 Kasım 1983 seçimlerine MGK'den onay alabilen ANAP, Halkçı Parti ve Milliyetçi Demokrasi Partisi katılabilmiştir (Özüerman, 1996: 53). 1980 Darbesi ile politika yapması yasaklanan Süleyman Demirel, Alparslan Türkeş, Bülent Ecevit ve Necmettin Erbakan'ın yasakları, 1987 yılında yapılan halk oylaması ile kaldırılmıştır. Bu dönemde yapılan 1983 ve 1987 seçimlerinden ANAP lider olarak çıkmayı başarmış ve tek parti iktidarını kurmuştur. Bu dönemde yaşanan politik ve ekonomik istikrarsızlığın en önemli kaynaklarını ise PKK terörü ve Banker Krizi ile birlikte Körfez Savaşı oluşturmuştur.

1980 yılı ile başlayan süreçte benimsenen iktisat politikaları ana hatları itibariyle 1989-2002 yıllarına da damgasını vurmuştur. Türkiye ekonomisi giderek artan boyutlarda sermaye hareketlerindeki dalgalanmaların etkisine ve sık sık tekrarlanan finansal kaos ve krizlerin tehdidine maruz kalmıştır. Bunda 32 Sayılı Kararname ile sermaye akımlarının serbestleştirilmesi kararının ardından yüksek faizli iç borçlanma nihayetinde faiz yükümlülüklerinin de giderek ek borçlanma ile karşılanması ve nihayetinde borcun borçla finansmanı anlamına gelen Ponzi finansmanının yerleşmesi etkili olmuştur. Sermaye hareketlerinden kaynaklanan konjonktür dalgalanmalarının iniş aşamasını temsil eder bir biçimde 1994, 1999 ve 2001 krizleri milli gelirde küçülmeye ve makroekonomik göstergeler üzerinde ciddi belirsizliklerin ortaya çıkmasına neden olmuştur (Boratav, 2005: 171-172, 178-180). Mesut Yılmaz önderliğindeki son tek başına ANAP iktidarının 1991 yılı Kasım ayında son bulmasının ardından ülke tekrar uzun vadeli bir koalisyon hükümetleri dönemine girmiştir. 2002 yılında yaşanan krize kadar Türkiye ekonomisi biri Demirel, biri Erdal İnönü, üçü Tansu Çiller, ikisi Mesut Yılmaz, biri Necmettin Erbakan ve ikisi de Bülent Ecevit olmak üzere on farklı koalisyon hükümeti tarafından yönetilmiştir. Politik gücün bu şekilde dağılması parlamentonun yasama ve hükümetin de yürütme gücünde ciddi tıkanmaları beraberinde getirmiştir (Arslan, 2007: 12). Bu dönemde politik istikrarsızlığın en önemli kaynağı kısa süreli koalisyon hükümetleri ve 28 Şubat 1997 post-modern darbesidir.

$\mathrm{Bu}$ dönemin önemli bir özelliği her krizin arkasından kendisini gösteren IMF anlaşmalarıdır. IMF reçetelerine bağlı olarak uygulamaya konulan istikrar paketleri başta TL'nin devalüe edilmesi, ek vergiler konulması ve yüksek oranlı KİT zamları olmak üzere çoğu zaman birbirlerine benzer tedbirleri içermiştir (Güloğlu \& Altınoğlu, 2002: 17). Yüksek enflasyon ile birlikte kısa vadeli sermaye girişlerince finanse edilen yüksek oranlı büyüme seçeneği olumsuz dış finansal koşulların neden olduğu her büyük çaplı sermaye çıkışında yeni bir IMF Stand-by antlaşmasını beraberinde getirmiştir. 1998 yılı Kasım ayında Mesut Yılmaz hükümetinin düşürülmesi, 1998 Rusya Krizi ve 1999 Marmara Depremi’nin ardından yüksek reel faiz-yüksek kamu borç stoku çıkmazının sürdürülemez 
hale gelmesiyle 1999 yılının Aralık ayında IMF'ye verilen niyet mektubu ile enflasyonla mücadele programı ele alınmıştır (Güloğlu, 2001: 1). Kasım 2000 Krizi, enflasyonu düşürme programının ilk bunalım deneyimi olmuştur. On aylık uygulama sonrasında mali piyasaların ön görülemeyen bir para kriziyle karşı karşıya kalması ve faiz hedeflerinin bir anda anlamını yitirmiş olması, programın devam edip etmeyeceği konusunda kuşkulara neden olmuştur. Kasım ayında mali sektörde çok ciddi bir kriz yaşanmış, önce para piyasalarında hissedilen sıkıntılar kendisini daha sonra sermaye piyasasında göstermiştir (Yıldırım, 2004: 50). IMF'den alınan destek sadece krizin daha fazla derinleşmesinin önüne geçebilmiş fakat 19 Şubat 2001 tarihinde Başbakan Ecevit ile Cumhurbaşkanı Ahmet Necdet Sezer arasında yaşanan politik bir kriz esasını cari işlemler açığının meydana getirdiği yeni ve daha şiddetli bir krize neden olmuştur (Karaçor \& Alptekin, 2006: 244,280). Krizin ardından EcevitBahçeli-Yılmaz hükümeti IMF ve Dünya Bankası'nın gözetiminde Ekonomiden Sorumlu Devlet Bakanı Kemal Derviş tarafından hazırlanan Güçlü Ekonomiye Geçiş Programı’nı (GEGP) hazırlamıştır. Güçlü Ekonomiye Geçiş Programı temelinde IMF ile 1999 yılında yapılan ve yürürlüğe konulan Stand-by anlaşmasının bir devamı niteliğindedir (Kandiller, 2009: 1).

Türk siyasi hayatı için yeniden uzun vadeli bir tek parti iktidarının kapısını açan 2002 seçimleriyle birlikte AKP'nin iktidar olması üzerine GEGP'yi uygulamak bu hükümete kalmıştır. AKP'nin güçlü bir çoğunlukla tek başına iktidara gelmesi ve politik istikrarı sürekli kılabilecek bir çoğunluğun sağlanması ekonomide olumlu bir hava oluşturmuştur. IMF ile yapılan Ocak 2002-Aralık 2004 dönemini kapsayan 18. Stand-by anlaşması yapılan gözden geçirmeler sırasında Şubat 2005'e uzatılmıştır. Ardından Mayıs 2005-Mayıs 2008 dönemini kapsayan 19. Stand-by anlaşması yapılmıştır. Bu anlaşmaya göre, güçlü ve istikrarlı büyüme, düşük enflasyon ve yeni istihdam olanaklarının sağlanması için temel politikaların oluşturulması hedeflenmiştir (Şanlısoy, 2007: 252). AKP iktidarı da kendi içerisinde 2002-2007 ve 2008-2015 olarak iki döneme ayrılabilir. AKP iktidarının ilk döneminde yakalanan hızlı büyüme oranlarının arkasında birçok diğer gelişmekte olan ülke gibi Türkiye'nin de 2001 yılını takip eden süreçte uluslararası konjonktürün sağladığı imkânlar dâhilinde büyük bir finansal genişleme ve ucuz kredi olanağına kavuşması bulunmaktadır. Bununla birlikte finansal genişlemeye bağlı olarak giderek artan dış açıklar ve cari işlemler açıkları önce düşük kur - yüksek faiz cazibesiyle Türkiye'ye akmakta olan sıcak parayla, daha sonraları ise şirket birleşmeleri ve özelleştirmeler ile elde edilen doğrudan yabancı yatırımlar ile karşılanmaya çalışılmıştır (Yeldan, 2008: 1).

Bu dönemin politik istikrarsızlık kaynaklarını ise 27 Nisan 2007 e-muhtırası, Gezi Parkı olayları, Suriye'de ortaya çıkan iç savaş, cemaat yapılanmasına yönelik operasyonlar, 17-25 Aralık yolsuzluk olayları, Merkez Bankası'nın bağımsızlı̆̆ı ve Başkanlık Sistemi tartışmaları ile açılım sürecinde ülkenin güney doğusunda ortaya çıkan gerginlikler meydana getirmiştir. 2007 yılında ABD kaynaklı olarak ortaya çıkan iktisadi krizin politik istikrarsızlık ile birleşmesi 2007-2015 döneminde iktisadi göstergeler üzerinde bozucu etkilere neden olmuştur. Söz konusu bozulmaya yönelik olarak öne sürülebilecek bir iddia; 2008 yılı itibariyle IMF programının resmen sona ermesi fakat yerine bir program konulamaması nedeniyle bir iktisat politikası boşluğunun oluşması ve hazırlanan mali kural 
politikasına ise uyulamamış olması da gösterilebilmektedir (Gürkaynak \& Böke, 2013: 66). Diğer bir iddia ise kamu kesiminde sağlanan başarının özel kesimde sağlanamaması ve yeni bir reform dalgasının hayata geçirilememesidir. Bunda AKP'nin devletin ekonomideki ağırlığını arttırarak denetleyici bir rol üstlenmeye başlaması da etkili olmuştur (Karakaya, 2015: 4).

Sonuçta dönemsel olarak özetlendiğinde Türkiye ekonomisi ele alınan 65 yıllık süreçte uluslararası konjonktür ile yakından ilişkili bir şekilde ve benimsenen hükümet politikaları eşliğinde iktisat politikalarında önemli dönüşümler yaşamıştır. DP iktidarında geçen ve dış kaynak girişine dayalı büyümenin şekillendirdiği 1950-60 dönemi; iç talebe dönük ve dış ticarette ithal ikameci yapısı ile aşırı değerli döviz kuru ve koruma rantlarından beslenen bir sermaye birikimine dayan 1963-1980 dönemi; dişa açılım modeli olarak adlandırılan ve ihracat teşviklerinin olanak sağladığı rantlardan ve emeğin ücret maliyetlerinin düşürülmesinden kaynaklanan iktisadi artık ile beslenen 1980-1989 dönemi, uluslararası sermaye hareketleri üzerindeki kontrollerin kaldırılması ile tamamlanan finansal serbestleştirme süreci ile şekillenen ve büyüme-kriz-istikrar çevrimleri olarak nitelendirilebilecek 1989-2002 dönemi ve son olarak yüksek kredi kullanımı ve tüketim, bunun yarattığı cari açık ve dış finansman bağımlılığı ve büyümede inşaat sektörünün önemli rol oynadığ́1 ekonomik modele dayanan 2002-2015 dönemi bu dönüşümün ana hatlarını teşkil etmektedir (Yeldan, 2001: 54; Karakaya, 2015: 5). Söz konusu değişimler ele alınan süreçteki performans değişikliklerini meydana getirmektedir.

\section{Literatür Taraması}

Literatürde hükümet performanslarının ölçülmesi doğrudan iktisadi göstergeler üzerinden gerçekleştirilebildiği gibi sosyal göstergeler üzerinden de gerçekleştirilebilmektedir. Yurtiçi literatürün şekillenmesinde veri kısıtı belirleyici olmuştur. Bu çerçevede birbirini takip eden hükümet dönemlerine ilişkin çalışmalar olduğu gibi tekil hükümetler dönemlerine ilişkin çalışmalar da mevcuttur. Uluslararası literatürde ise performans ölçümlerinin etkinliğinin arttırılmasına yönelik çalışmalar çoğunluktadır. Bununla birlikte ulusal hükümetler ile birlikte yerel yönetimlerin etkinliklerinin ölçülmesi de çalışmalarda kendisine yer bulmuştur. Geliştirilen endekslerle birlikte parametrik olmayan yöntemler her iki düzeyde de performans ölçümlerinin temel aracı olmuştur.

Telatar (2000), Okun tipi, Barro tipi ve Yeniden Düzenlenmiş Endeksler ile Türkiye ekonomisine ilişkin farklı hükümet dönemlerini ele almıştır. Menderes (1950-60), İnönü (1961-65), Demirel (1965-71), Özal (1983-91) ve Çiller (DYP-CHP koalisyonu) dönemleri için her bir endeks tipinde hangi dönemin daha başarılı olduğu test edilmiş; Okun tipi ve Yeni Düzenlenmiş endeks ortak sonuç vererek İnönü hükümetlerinin en başarılı ve Çiller hükümetlerinin ise en başarısız hükümetler olduğu sonucuna ulaşmıştır.

Türkiye ekonomisini ele alan çalışmalardan Kaynak ve Balcı (2009), parasal ve parasal olmayan değişkenleri kullandıkları çalışmalarında 1923-2007 dönemi için hükümetlerin performanslarını faktör analizi yöntemi ile test etmişlerdir. Çalışmanın 
sonucunda kısa süreli tek parti ve koalisyon hükümetlerinin uzun süreli tek parti iktidarlarına göre daha başarısız oldukları belirlenmiştir. Çalışma, sağlık, milli hesaplar, maliye, dış ticaret, eğitim ve madencilik gibi farklı alanlarda en başarılı ve en başarısız hükümetlerin tespitine odaklanmıştır.

Endeksler üzerinden değerlendirme yapan bir diğer çalışma da Kibritçioğlu (2007) olmuştur. 1987-2007 döneminin farklı makroekonomik performans endeksleri için değerlendirildiği çalışmada yapılan analizlerin sonucunda RP-DYP en başarılı hükümet olurken 1993 ile 1996 yılları arasında görev yapan DYP-SHP, DYP ve DYP-CHP hükümetleri en başarısız hükümetler olmuştur.

Eleren ve Karagül (2008), 1980-2006 dönemi için çoklu karar verme yöntemi yardımıyla hükümet performanslarını değerlendirmiştir. Büyüme, cari açık, enflasyon, tüfe, işsizlik ve kamu borç faiz oranı değişkenlerinin kullanıldığ çalışma hükümetlerin iktisadi anlamda hangi yıl daha başarılı olduğunu analiz etmiş ve hesaplanan başarı puanları neticesinde sırasıyla 1986, 1990, 1987 ve 1993 yıllarının en başarılı yıllar, 1999, 2001, 2006 ve 2000 yıllarının ise sırasıyla en başarısız yıllar olduğu sonucuna ulaşmışlardır.

Strom (1985), çalışmasında hükümet performansının ölçülmesine ilişkin dört yeni ölçüm kriteri sunmaktadır. Bunlar yönetim süresi, iktidarın ne şekilde bırakıldığı, müteakip hükümet değişimleri ve seçim başarısıdır. Çalışmada azınlık hükümetlerin geleneksel görüş çerçevesinde daha zayıf bir performans sergileyecekleri hipotezi parlamenter demokrasi ile yönetilen 15 ülke için 323 savaş sonrası hükümetinde test edilmiş ve elde edilen sonuçlar neticesinde hipotez reddedilmiştir. Çalışmanın bulguları, azınlık hükümetlerinin rasyonel kabine çözümü olarak desteklenebileceğini ifade etmektedir.

Barro (1996), Okun Endeksi'nden hareketle oluşturduğu endeksi kullanarak ABD ve İngiltere hükümetlerinin performanslarını analiz etmiştir. Çalışma Okun Endeksi'nin açıklarını kapatmak için ele alınan ekonomik değişkenlerin önceki dönem değerlerini de analize dâhil etmiştir. Analizde enflasyon oranı (TÜFE artış oranı), işsizlik oranı, işsizlik ve enflasyon oranlarının önceki değerleri, faiz oranı (uzun dönem devlet tahvili getirisi) ve GSYİH'nin büyüme oranı (reel büyüme oranı) değişkenleri kullanılmıştır. Analiz sonuçları; ABD özelinde Reagan hükümetlerinin (1981-84 ve 1985-88) en iyi performansı sergilerken İngiltere özelinde ise Callaghan (1976-79) hükümeti ekonomik performans açısından en başarılı hükümet olmuştur.

Boix ve Posner (1998), tarihsel bir perspektifle ve kuramsal çerçevede ele aldıkları çalışmalarında sosyal sermaye ile hükümet performansları arasındaki ilişkiyi ele almışlardır. Bunun için öncelikle sosyal sermayenin kökenini araştırmışlar; daha sonra ise sosyal sermaye ile hükümet performansı arasındaki ilişkiyi meydana getiren mekanizmayı ortaya koymaya çalışmışlardır. Söz konusu mekanizmayı oluşturan faktörlerin rasyonel seçmenler, rekabetçi elitler, kurallara riayet, bürokratik etkinlik, sivil erdem ve elit yerleşim olduğunu öne sürmüşlerdir. 
Brender (2003), İsrail örneğinde mali performansın tekrar seçilebilme ihtimali üzerindeki etkisini incelemiş ve 1998 seçimlerinde söz konusu etkinin olduğu fakat 1989 ve 1993 seçimlerinde olmadığı sonucuna ulaşmıştır. Çalışmada uygulanan regresyon analizi, mali değişkenlerin yerel anlamda gelir düzeyini yahut yöneticilerin kaynak yaratım sürecindeki başarısını yansıttığı hipotezlerini de reddetmiştir.

Coll, Prior ve Ausina (2006), İspanya'nın Valencia bölgesi için yerel hükümetlerin etkinliğini analiz etmiştir. Analizin ilk aşamasında veri zarflama analizi ve FDH (Free Disposable Hull) teknikleri ile non-parametrik olarak etkinlik ölçümü yapılmış ve ikinci aşamada ise politik ve mali politika değişkenleri üzerinden etkinliğin önemli belirleyenleri tanımlanmıştır. Elde edilen etkinlik değerleri FDH tekniğinin dış bükey olmama varsayımı altında daha geniş belediyeler için daha yüksektir. Dolayısıyla daha büyük belediyelerin kaynak tahsisatını daha başarılı bir şekilde gerçekleştirebildiği ifade edilmiştir.

\section{Veri Seti ve Yöntem}

Çalışmada hükümet performanslarının iktisadi alandaki belirleyenleri olarak ekonomik süreç politikası araçlarından hareketle büyüme, işsizlik, enflasyon, faiz oranı, kamu diş borç stoku, cari açık ve bütçe açığı değişkenleri seçilmiştir. Dönem aralığı olarak ise çok partili seçimlerin fiili olarak gerçekleştirildiği 1950 yılından 2015 yılına kadar olan dönem ele alınmıştır. Değişskenlere ilişkin veriler, TÜİK (1923-2013) İstatistik Göstergeler yayınından, TCMB elektronik veri dağıtım sisteminden, Kalkınma Bakanlığı'nın internet sitesi vasıtasıyla yayınladığı gösterge ve istatistiklerden, Maliye Bakanlığı Muhasebat Genel Müdürlüğü’nden ve Hazine Müsteşarlığı'ndan elde edilen verilerle derlenmiştir. Büyüme ve enflasyon verileri 1968 yılı sabit fiyatları ile alınmış, Net Kamu Dış Borç Stoku yüzde değişim olarak hesaplanmıştır. Bütçe açığı ve cari açık değişkenleri GSMH'ye olan oranları cinsinden ifade edilmiştir. Faiz oranı verisi ise ekonomideki para arzı ve kredi genişlemesinin dikkate alınması amacıyla TCMB'nin kısa vadeli reeskont faiz oranı olarak seçilmiştir.

Çalışmada hükümetlerin performans sıralamasını yapmak amacıyla TOPSIS yöntemi kullanılmıştır. Hwang ve Yoon (1981) tarafından geliştirilen TOPSIS yöntemi pozitif ve negatif ideal çözümlerin referans noktası olarak seçilmesine dayanmaktadır (Lai, Liu \& Hwang, 1994: 486-500). Pozitif ideal çözüm fayda kriterlerini maksimize eden ve zarar kriterlerini ise minimize eden çözümdür. Negatif ideal çözüm ise zarar kriterlerini maksimize eden ve fayda kriterlerini ise minimize eden çözümdür. Seçilecek optimal alternatif, pozitif ideal çözüme en kısa ve negatif ideal çözüme ise en uzak Öklid mesafesindedir (Tzeng \& Huang, 2011: 69). TOPSIS yönteminin çözüm aşamaları; normalize karar matrisinin ve ağırlıklandırılmış normalize karar matrisinin hesaplanması, pozitif ve negatif ideal çözümlerin belirlenerek ideal çözüm noktasına olan uzaklıkların hesaplanması, ideal çözüme göreli yakınlıkların hesaplanması ve son olarak da alternatiflerin azalan sirada siraya dizilmesi sonucunda tercih siralanmasının belirlenmesinden meydana gelmektedir (Yaralığlu, 2010: 23-28). 
TOPSIS yönteminde değerlendirmeye alınan kriterlerin önem dereceleri aynı olmayabilir. $\mathrm{Bu}$ durum değerlendirme kriterlerinin farklı anlamlar içermesinden kaynaklanmaktadır. $\mathrm{Bu}$ nedenle kriterlerin ağırlıklandırılmasında ele alınan problemin doğasına ve niteliğine bağlı olarak, farklı yöntemler kullanılabilir. Analitik Hiyerarşi Süreci (AHP), Eigen Vektör, Entropy gibi yöntemler kriterlerin ağırlıklandırılmasında kullanılan yöntemlerden bazılarıdır (Chu, 2007: 1015).

\section{Bulgular}

$\mathrm{Bu}$ çalışmada kriterlerin ağırlıklandırılmasında ilk önce her bir kriterin eşdeğer ağırlığa sahip olduğu varsayılarak performans puanları hesaplanmış; ardından karşılaştırma yapılabilmesi amacıyla ANP (Analitik Ăg Süreci)'ye göre belirlenmiş ağırlıklar kullanılmıştır. ANP ağırlıklarının elde edilmesinde Super Decisions programı kullanılmıştır. AHP'nin temel esasları ve ikili karşılaştırma mantığı ANP yönteminde de geçerlidir. Bununla birlikte AHP, karar düzeyleri arasında tek yönlü bir hiyerarşik ilişkinin varlığ durumunda tercih edilmekte iken ANP, karar düzeyleri arasında kompleks karşılıklı ilişkilerin varlığı durumunda analiz yapılmasına imkan vermektedir (Yüksel ve Dağdeviren, 2007: 3364). Ağırlıkların belirlenmesi anlamında üçlü bir kıyaslamanın yapılabilmesi amacıyla bir diğer ağırlık belirleme yöntemi olarak da E. S. Kirchen ve diğerleri tarafından iktidardaki partilerin sosyal demokrat, merkez ve muhafazakâr kimliğine göre belirlenmiş amaçların ordinal sıralaması kullanılmıştır. Genel bir eğilimi yansıtan bu çalışmaya göre sosyal demokrat partiler büyüme, tam istihdam ve gelir dağılımının düzeltilmesi amaçlarını daha öncelikli olarak benimserken; liberal ve merkez partiler fiyat istikrarı ve büyümeyi ve muhafazakâr partiler ise öncelikle fiyat istikrarı ardından ise ödemeler dengesi amaçlarını ön planda tutmaktadır (Erkan, 2000: 157). Buna göre belirlenen kriter ağırlıkları Tablo 1'de gösterilmiştir.

Tablo: 1

\section{Değerlendirme Kriterlerinin Ağırlık Değerleri}

\begin{tabular}{|l|r|r|r|}
\hline \multicolumn{1}{|c|}{ Kriterler } & ANP Ă̆ırlıkları & Eşit Ă̆ırlıklar & \multicolumn{1}{c|}{ Kirschen vd. } \\
\hline Büyüme & 0,3768475 & 0,142857143 & 0,214285714 \\
\hline İşsizlik & 0,1365627 & 0,142857143 & 0,190476190 \\
\hline Enflasyon & 0,1339627 & 0,142857143 & 0,214285714 \\
\hline Faiz Oranı & 0,1902638 & 0,142857143 & 0,107142857 \\
\hline Dış Borç & 0,0826817 & 0,142857143 & 0,047619048 \\
\hline Cari Açık & 0,0489010 & 0,142857143 & 0,166666667 \\
\hline Bütçe Açı̆ı̆ & 0,0307806 & 0,142857143 & 0,059523810 \\
\hline Toplam & 1 & 1 & 1 \\
\hline
\end{tabular}

Belirlenen kriter ağırlıkları çerçevesinde elde edilen performans değerleri Grafik 1 'de karşılaştırmalı olarak gösterilmiştir. Buna göre her üç ağırlık değerinde de en yüksek puanı 1960 Darbesi'nin ardından iktidara gelen CHP-YTP-CKMP (25.06.1962- 25.12.1963) hükümeti almıştır. 1970'li yılların sonundaki krizlerin ve 1980 askerî darbesinin ardından 1983 seçimleriyle iktidara gelen ANAP'ın ve 2002 krizi sonrasında iktidara gelen AKP'nin 
performans sıralamasında üst sıralarda kendisine yer bulmasının en önemli nedeni ekonomik ve politik istikrarsızlık sonrasında iktidara gelmiş olmalarıdır. En düşük puan ise eşit ağırlık ve ANP'ye göre uygulanan ağırlık durumlarında 1979 yılı Kasım ayından 1980 Darbesi'ne kadar iktidarda olan Adalet Partisi ve Kirschen vd.'e göre belirlenen ağırlıklar durumunda ise Türkiye siyasetinde yoğun çalkantıların yaşandığ ${ }_{1}$ CHP (1978-1979) hükümetine aittir. Bununla birlikte yaşanan her siyasi krizin ardından uzun vadeli bir tek parti hükümeti iktidara gelmekte, bu hükümetler ikinci ve üçüncü dönemlerinde ilk dönemlerine göre daha düşük bir performans sergilemekte ve yerlerini koalisyon hükümetlerine birakmaktadır. Koalisyon hükümetleri de yaşanan siyasi ve ekonomik krizlerin ardından yerlerini yine tek parti iktidarlarına bırakmaktadır. Bu durumun tek istisnasını 2015 seçimlerinin ardından iktidarını koruyan AKP ve en yüksek puanı alan CHP/YTP/CKMP iktidarı oluşturmaktadır. Grafiksel gösterimden ayrı olarak sıralı liste ekte verilmiştir.

\section{Grafik: 1}

\section{Belirlenmiş Ă̆ırlıklar Çerçevesinde Hükümet Performansları}

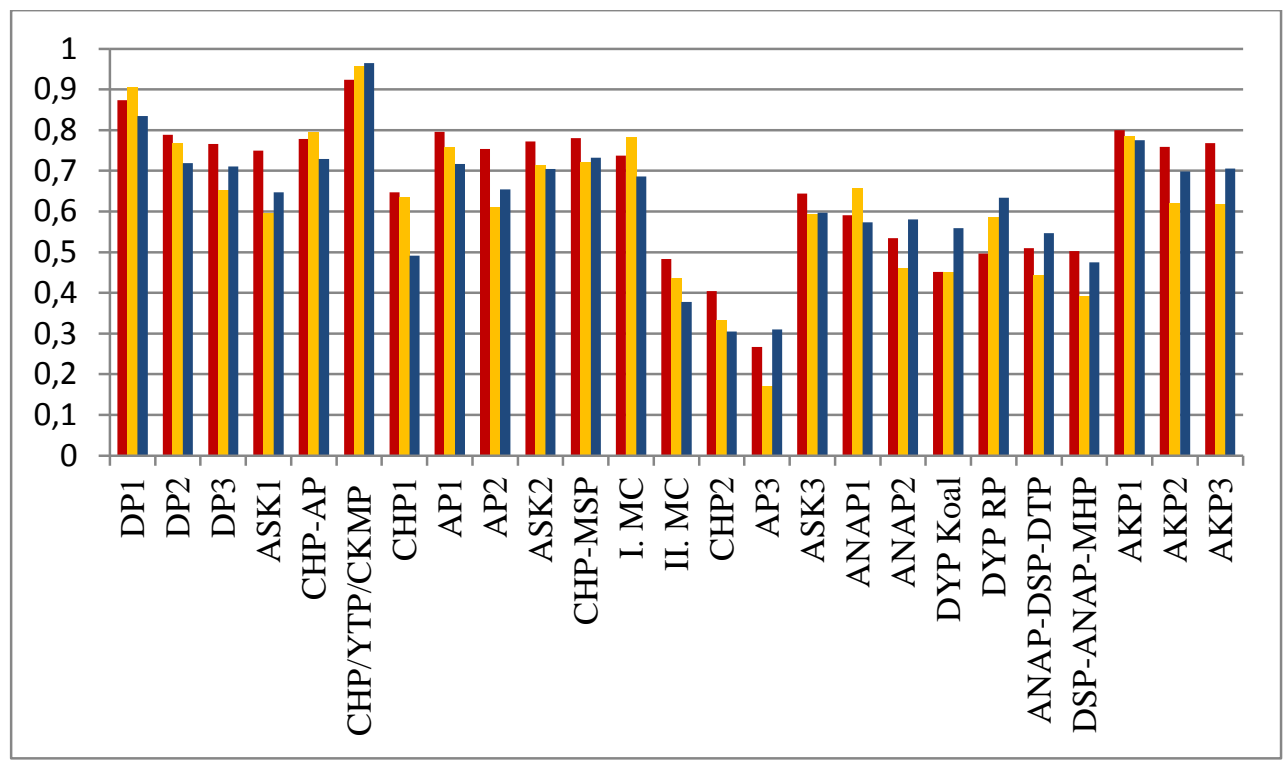

Çalışmanın bir sonraki adımında tek parti iktidarları, koalisyon hükümetleri ve askerî-geçici hükümetler belirlenen kriter ağırlıkları çerçevesinde karşılaştırılmıştır. Tablo 2'de hükümet tipleri için belirlenen kriterlere ilişkin veriler ve Tablo 3 'te ise bu verilerinin standardize edilmiş değerleri bulunmaktadır.

Verilerin standardizasyonu kriter değerlerinin bire bölümü ile elde edilmiştir. Böylelikle kriter değişkenleri olan işsizlik, enflasyon, faiz oranı, dış borç, cari açık ve bütçe 
açığı, hedef değişkenleri olan istihdam, fiyat istikrarı, dış alacak, cari fazla ve bütçe fazlasına dönüştürülmüştür.

Tablo: 2

Farklı Hükümet Tipleri İçin Kriter Verileri

\begin{tabular}{|l|c|c|c|}
\hline Kriter & Tek Parti & Koalisyon & Ask-Geçici Hük. \\
\hline Büyüme & 0,051525 & 0,045167 & 0,044000 \\
\hline İşsizlik & 0,083955 & 0,082388 & 0,076775 \\
\hline Enflasyon & 0,216527 & 0,501388 & 0,208375 \\
\hline Faiz Oranı & 0,198875 & 0,376527 & 0,182500 \\
\hline Diş Borç & 0,097342 & 0,107194 & 0,123287 \\
\hline Cari Açık & 0,030310 & 0,018700 & 0,013525 \\
\hline Bütçe Açı̆̆ & 0,021480 & 0,059639 & 0,010963 \\
\hline
\end{tabular}

Tablo: 3

Kriter Verilerinin Standardize Edilmiş Değerleri

\begin{tabular}{|l|r|r|r|}
\hline Kriter & \multicolumn{1}{|l|}{ Tek Parti } & \multicolumn{1}{l|}{ Koalisyon } & Ask-Geçici Hük. \\
\hline Büyüme & 0,051525 & 0,045167 & 0,044000 \\
\hline İstihdam & 11,911143 & 12,137559 & 13,025073 \\
\hline Fiyat İstikrarı & 4,618351 & 1,994460 & 4,799040 \\
\hline Faiz Oranı & 5,028284 & 2,655847 & 5,479452 \\
\hline Diş Alacak & 10,273005 & 9,328842 & 8,111122 \\
\hline Cari Fazla & 32,992412 & 53,475936 & 73,937153 \\
\hline Bütçe Fazlası & 46,554935 & 16,767583 & 91,220068 \\
\hline
\end{tabular}

Belirlenen ağırlıklar neticesinde farklı hükümet tipleri için elde edilen puanlar ise Tablo 4'te verilmektedir. Buna göre gerek eşit ağırlıkların kullanıldığı analiz sonucunda gerekse ANP ve Kirschen vd. ile elde edilen ağırlıkların kullanıldığg analiz sonucunda askeri-geçici hükümetler birinci sırayı elde etmiştir. Benzer şekilde her iki analizin neticesinde tek parti iktidarları ikinci sırayı alırken koalisyon hükümetleri ise son sırayı almıştır.

Tablo: 4

\section{Hükümet Tiplerinin Karşılaştırılması}

\begin{tabular}{|l|c|c|c|}
\hline \multirow{2}{*}{\multicolumn{1}{|c|}{ Hükümet Tipleri }} & \multicolumn{3}{c|}{ Ăğrlık } \\
\cline { 2 - 4 } & Eşit & ANP & Kirschen vd. \\
\hline Tek Parti Hükümetleri & 0,490073 & 0,378334 & 0,458600 \\
\hline Koalisyon Hükümetleri & 0,195154 & 0,155449 & 0,137414 \\
\hline Askerî-Geçici Hükümetler & 0,858856 & 0,938509 & 0,818681 \\
\hline
\end{tabular}

Analizin son aşamasında politik konjonktüre bağlı olarak benimsenen farklı ekonomi politikası dönemleri için bir sıralama yapılmıştır. Bu çerçevede Türkiye ekonomisi, DP hükümetlerinin iktidarda olduğu devletçilikten dışa açık ekonomiye geçiş, 1960 Darbesi'nin ardından 1980 Darbesi'ne kadar sürecek olan ithal ikameci sanayileşme, 1983 seçimleriyle birlikte iktidara gelen ANAP'ın iktidar süresinin büyük kısmına egemen olan 
ihracata dayalı büyüme ve 1989 yılında 32 Sayılı Karar neticesinde sermaye akımlarının serbestleştirilmesiyle birlikte ortaya çıkan ve günümüze kadar devam eden sıcak paraya dayalı büyüme dönemleri olarak ele alınmıştır. Bölümleme sırasında askerî-geçici hükümetler, iktisadi politikaları yönlendirme konusunda önceki dönem politikalarının bir devamı niteliğinde olduklarından ve önceliklerini iktisat politikasının değiştirilmesinden ziyade ülke içi istikrarın sağlaması oluşturduğundan analiz dışı bırakılmıştır. Buna göre farklı politika dönemlerine ilişkin veriler Tablo 5 'te verilmektedir.

Tablo: 5

Farklı Politika Dönemleri İçin Kriter Verileri

\begin{tabular}{|l|r|r|r|r|}
\hline \multicolumn{1}{|c|}{ Kriter } & $\begin{array}{c}\text { Dişa Açık } \\
\text { Ekonomiye Geçiş }\end{array}$ & $\begin{array}{c}\text { İthal İkameci } \\
\text { Sanayileşme }\end{array}$ & $\begin{array}{c}\text { İhracata Dayalı } \\
\text { Sanayileşme }\end{array}$ & \multicolumn{2}{c|}{$\begin{array}{c}\text { Sicak Paraya Dayalı } \\
\text { Sanayileşme }\end{array}$} \\
\hline Büyüme & 0,0699 & 0,049062 & 0,049666 & 0,042 \\
\hline İsssizlik & 0,06971 & 0,082443 & 0,080166 & 0,090153 \\
\hline Enflasyon & 0,0884 & 0,221437 & 0,529166 & 0,38785 \\
\hline Faiz Oranı & 0,038 & 0,092812 & 0,508333 & 0,377596 \\
\hline Dış Borç & 0,0737 & 0,190112 & 0,128416 & 0,0359507 \\
\hline Cari Açık & 0,01948 & 0,024325 & 0,006966 & 0,0594 \\
\hline $\begin{array}{l}\text { Bütçe } \\
\text { Açığı }\end{array}$ & 0,0019 & 0,010825 & 0,0326833 & \\
\hline
\end{tabular}

Verilerin analiz için standardize edilmiş değerleri yine verilerin bire bölümü ile elde edilmiş ve elde edilen değerler Tablo 6'da verilmiştir.

Tablo: 6

Kriterlerin Standardizasyonu

\begin{tabular}{|l|r|r|r|r|}
\hline \multicolumn{1}{|c|}{ Kriter } & $\begin{array}{c}\text { Dışa Açı } \\
\text { Ekonomiye Geçiş }\end{array}$ & \multicolumn{1}{c|}{$\begin{array}{c}\text { İthal Íkameci } \\
\text { Sanayileşme }\end{array}$} & $\begin{array}{c}\text { Íhracata Dayalı } \\
\text { Sanayileşme }\end{array}$ & \multicolumn{1}{c|}{$\begin{array}{c}\text { Sicak Paraya Dayalı } \\
\text { Sanayileşme }\end{array}$} \\
\hline Büyüme & 0,0699 & 0,049062 & 0,049666 & 0,042 \\
\hline İstihdam & 14,34514 & 12,129482 & 12,474012 & 11,09215 \\
\hline $\begin{array}{l}\text { Fiyat } \\
\text { İstikrarı }\end{array}$ & 11,31221 & 4,515946 & 1,889763 & 2,57831 \\
\hline Faiz Oranı & 26,31578 & 10,774410 & 1,967213 & 2,64833 \\
\hline Dıș Alacak & 13,56852 & 5,260043 & 7,787151 & 20,40976 \\
\hline Cari Fazla & 51,33470 & 41,109969 & 143,540669 & 28,16291 \\
\hline $\begin{array}{l}\text { Bütçe } \\
\text { Fazlası }\end{array}$ & 526,3157 & 92,378752 & 30,596634 & 16,83501 \\
\hline
\end{tabular}

Tablo: 7

Farklı Politika Tiplerinin Karşılaştırılması

\begin{tabular}{|l|c|c|r|}
\hline \multicolumn{1}{|c|}{ Politika Tipleri } & \multicolumn{3}{c|}{ Ă̆ırlık } \\
\cline { 2 - 4 } & Eşit & ANP & \multicolumn{1}{c|}{ Kirschen vd. } \\
\hline Dişa açık ekonomiye geçiş & 0,7102355 & 0,7251522 & 0,750211259 \\
\hline İthal ikameci sanayileşme & 0,2247776 & 0,1493356 & 0,166602629 \\
\hline İhracata dayalı sanayileşme & 0,3202664 & 0,3197148 & 0,189970136 \\
\hline Sicak paraya dayalı büyüme & 0,2619917 & 0,1668897 & 0,394601037 \\
\hline
\end{tabular}


Belirlenen ağırlıklar neticesinde farklı iktisat politikası dönemleri için elde edilen puanlar ise Tablo 7'de görülmektedir.

Puanlamaya ilişkin elde edilen sonuçlar neticesinde her üç ağırlıklandırma için de dışa açık ekonomiye geçiş döneminin o dönemde elde edilen yüksek büyüme oranları ve düşük faiz oranlarının da etkisiyle ilk sırada yer aldığı görülmektedir. İthal ikameci sanayileşme dönemi ise yine her üç ağırlıklandırmada da son sıradadır. Bunda 70'li yılların kriz dönemlerinde büyümenin negatife dönmesi ve yine krize bağlı olarak enflasyon ve işsizlik oranlarının hızla yükselmesi etkili olmuştur. Sıcak paraya geçiş dönemi de ithal ikameci sanayileşme dönemine yakın bir puan alarak ANP ve eşit ağırlıklar için üçüncü sırayı alırken Kirschen vd. için ikinci sırayı almıştır.

\section{Sonuç ve Değerlendirme}

Son dönem Türkiye siyasi ve ekonomik hayatındaki gelişmeler, farklı hükümet tiplerine ve politika uygulamalarına yönelik tartışmaların temelini oluşturmaktadır. $\mathrm{Bu}$ bakımdan farklı hükümetlerin gerek iktidar yapısı gerekse eko-politik alt dönemler itibariyle performanslarının karşılaştırılması oldukça önemlidir. Temel ekonomik göstergeler kullanılarak 1950-2015 dönemi için TOPSİS analizinin uygulandığ bir karşılaştırmanın yapılabilmesi amacıyla üç farklı ağırlık kullanılmış ve hükümetler hem kendi içerisinde, hem iktidarın yapısı ve hem de ekonomik sistemin yapısı açısından sıralanmıştır.

Yapılan analizlerin sonucunda, kullanılan ağırlıkların tutarlı sonuçlar verdiği görülmüştür. Analizlerin sonucunda her üç ağırlık için de en yüksek puanı elde eden CHP/YTP/CKMP hükümeti ise 1960 Darbesi sonrasında ithal ikameci sanayileşme döneminin ilk hükümetidir. İktidarın yapısı anlamında tek parti iktidarları koalisyon hükümetlerine göre daha yüksek puan almıştır. Ekonomik performansın en yüksek olduğu dönem ise dışa açık ekonomiye geçiş dönemidir. Bu anlamda Demokrat Parti iktidarında teşkil edilen hükümetler en başarılı olmuştur. Bununla birlikte çok sayıda koalisyon hükümetinin görevde bulunduğu ithal ikameci sanayileşme dönemi ve sıcak paraya dayalı büyüme dönemi, koalisyon hükümetlerinin düşük performansları nedeniyle dışa açık ekonomiye geçiş dönemine göre daha başarısız olmuştur.

İktidar yapısı itibariyle en düşük puanları ise koalisyon hükümetleri almıştır. 1974 Petrol Krizi'ni takiben iktidarda olan hükümetler bu anlamda 1990'lı yılların zayıf konjonktüründe iktidarda bulunan hükümetlere göre daha düşük puanlar almıştır. Siyasi sistemdeki süreklilikleri kısıtlı olmasına karşın askerî ve geçici hükümetler, iktidarın yapısı anlamında en yüksek performans puanını almıştır. Bu durum askerî hükümetlerin popülist bir gaye gütmemeleri yahut uzun vadeli bir eko-politik perspektife sahip olmamalarıla ilişkilendirilebilir.

Tüm bu sonuçlar değerlendirildiğinde ekonomik alan ile politik alanın etkileşimi dikkate alındığında ekonomik performansının artmasını isteyen bir Türkiye'nin hem politik 
hem de ekonomik alanda bir takım değişiklikler yapması gerektiği ortadadır. Politik alanda yapılacak değişiklikler, siyaset bilimcilerin alanına girmekle birlikte bu çalışma sonuçlarından hareketle koalisyon hükümetlerinin yerine tek parti iktidarlarının savunulması günümüzün demokrasi anlayışıyla uyumlu değildir. Kaldı ki Türkiye'de politik alan uzun yıllar boyunca koalisyon hükümetlerini ortaya çıkarmış olup kendine özgü koşullar nedeniyle de çıkarmaya devam edecektir. Öte yandan ekonomi politikaları yönünden hükümet performansları değerlendirildiğinde görülmektedir ki sıcak para girişlerine dayalı ekonomi politikalarının uygulandığı son dönemde hükümet performansı düşmektedir. Bunda etkili olan faktör de özellikle kriz dönemlerinde spekülatif yabancı sermayenin hızla ülkeyi terk etmesi ve krizleri derinleştirmesidir. Bu noktada yapılması gereken bu sermaye çıkışlarını engelleyici bir takım ekonomi politikası önlemlerinin alınmasıdır. Ancak içinde bulunduğumuz dönem itibariyle bunun gerçekleştirilmesi pek mümkün görülmemektedir. Spekülatif yabancı sermayenin bu kadar yoğun bir şekilde bulunduğu bir ekonomik ortamla birlikte yaşanan politik istikrarsızlık süreci, bu yönde uygulanacak bir ekonomi politikasının ekonomiyi bir krize sokmasını muhtemel hale getirmektedir. Bu durumda yapılması gereken kurulacak güçlü bir hükümet ile uzun dönemli ekonomi politikalarını içerene ve ekonomideki sektörel ve mekânsal paylar üzerinde etkili olan ekonomik yapı politikasında bir dönüşümün sağlanarak sıcak paraya dayalı ekonomik yapıdan kurtulunmasıdır.

Bununla birlikte ekonomik yapı politikası uygulamasında yürürlüğe konulması gereken bir başka politika değişikliği ülkenin üretim desenine ilişkindir. Bu amaçla hızla katma değeri yüksek ürünler ile bilgi ve teknoloji üretimine geçilmesi gerekmektedir. Uzun vadeli bu politika değişimi, bir yandan cari açığın azalmasını ve büyümenin hızlanmasını sağlarken diğer yandan ekonominin dişa bağımlılı̆̆ını azaltacaktır. Ancak bunun gerçekleştirilmesi de Türkiye'de bilgi ekonomisinin temel unsurlarında yaşanacak gelişmelere bağlı olacaktır. Bilgi ekonomisinin temel unsurları olan bilgi, bilgi işçisi ve bilgi iletişim teknolojilerine yapılacak olan yatırımlar veya katkılar Türkiye ekonomisinin hızlı bir şekilde gelişmesine katkı sağlayacaktır. Burada kritik olan faktör, bilgi işçileridir ve bunların yetiştirilmesi ülkenin eğitim politikalarıyla ilgilidir. Dolayısıyla eğitim politikasında gerçekleştirilecek dönüşüm bir yandan demokrasi kültürünün yerleştirilmesi açısından önemliyken; diğer yandan bilgi işçilerinin yetiştirilmesi açısından önemlidir. Burada eğitimin niceliği kadar, hatta belki de ondan daha önemlisi niteliğidir. Eğitim politikası yenilikçi, yaratıcı, sorgulayan, insan haklarına saygılı, uzlaşma-hoşgörü kültürüne sahip ve ezberden uzak bir birey yetiştirmeye yönelik bir yapıya kavuşturulmalıdır.

\section{Kaynaklar}

Akşin, S. (2000), Ana Çizgileriyle Türkiye’nin Yakın Tarihi 2, İmaj Yayınevi, Ankara.

Arslan, A. (2007), “12 Eylül 1980 Askeri Müdahalesi Sonrası Türkiye’nin Siyasi Yapısı”, Akademik Bakış, 11, Ocak.

Barro, R.J. (1996), Getting It Right Markets and Choices in a Free Society, The MIT Press, Cambridge, London.

Boratav, K. (2005), Türkiye İktisat Tarihi, 1908-2002, İmge Kitabevi, 9. Bask1, Ankara. 
Boix, C. \& D.N. Posner (1998), "Social Capital: Explaining Its Origins and Effects on Government Performance", British Journal of Political Science, 4, 686-693.

Brender, A. (2003), "The Effect Fiscal Performance on Local Government Election Resutls in Israel: 1989-1998”, Journal of Public Economics, 87, 2187-2205.

Chu, M. (2007), “Comparison among Three Analytical Methods for Knowledge Communities Group Decision Analysis", Expert Systems with Aplications, 33, 1011-1024.

Coll, M.T.B. \& D. Prior \& E.T. Ausina (2007), "On the Determinants of Local Government Performance: A Two-stage Nonparametric Approach”, European Economic Review, 51, 425-451.

Eleren, A. \& M. Karagül (2008), “1986-2006 Türkiye Ekonomisinin Performans Değerlendirmesi”, Yönetim ve Ekonomi, 15(1), 1-14.

Erkan, H. (2000), Ekonomi Politikasının Temelleri, 4. Baskı, İlkem Ofset, İzmir.

Güloğlu, B. (2001), "İstikrar Programından İstikrarsızlığa (Kasım 2000 ve Şubat 2001 Krizleri)”, Yeni Türkiye Dergisi, Kriz Özel Sayısı I, Ekim.

Güloğlu, B. \& E. Altınoğlu (2002), "Finansal Serbestleşme Politikaları ve Finansal Krizler: Latin Amerika, Meksika, Asya ve Türkiye Krizleri”, Istanbul Üniversitesi Siyasal Bilgiler Fakültesi Dergisi, 27, Ekim.

Güngen, A.R. (2006), “1980’ler Türkiye’sinde Devletin Yeniden Yapılandırılmasına Dair Yaklaşımlar Üzerine Eleştirel Notlar”, Mülkiye Dergisi, 30(250), Ankara.

Gürkaynak, R.S. \& S.S. Böke (2013), “AKP Döneminde Türkiye Ekonomisi”, Birikim Dergisi, 296, Aralık.

Kandiller, R. (2009), Güçlü Ekonomiye Geçiş Programı ve Ötesi, <http://www.dtm.gov.tr/dtmadmin /upload /EAD/.../ ekonomi1.doc>, 13.09.2009.

Karaçor, Z. \& V. Alptekin (2006), "Finansal Krizlerin Önceden Tahmini Yoluyla Değerlendirilmesi: Türkiye Örneği”, Celal Bayar Üniversitesi İIBF Yönetim ve Ekonomi Dergisi, 13(2), 237-256.

Karpat, K. (2010), Türk Demokrasi Tarihi, Sosyal, Kültürel, Ekonomik Temeller, Timaş Yayınları.

Karakaya, K. (2015), Pamuk: AK Parti'nin Ekonomi Modeli Uzatmaları Oynuyor, <http://www.wsj.com.tr>, 27.06.2015.

Kaynak, M. \& Ö. Balcı (2009), "Kalkınma Performansları Açısından Cumhuriyet Hükümetleri: 1923-2007”, 11. Sosyal Bilimler Kongresi, 9-11 Aralık 2009, Ankara.

Keyder, Ç. (2008), Türkiye'de Devlet ve Sınıflar, İletişim Yayınları, 13. Baskı, İstanbul.

Kibritçioğlu, A. (2007), A Comparison of Macroeconomic Performances of Governments in Turkey 1987-2007, <http://mpra.ub.uni-muenchen.de/3962/1/MPRA_paper_3962.pdf>, 21.07.2015.

Koçak, C. (1997), "Siyasal Tarih (1923-1950)”, içinde: Türkiye Tarihi 4, Çağdaş Türkiye (19081980), Yayın Yönetmeni: Sina Akşin, Cem Yayınevi, İstanbul.

Lewis, B. (2007), Demokrasinin Türk Serüveni, Çev. Esra Ermert ve Ahmet Hamdi Aydoğan, Yap1 Kredi Yayınları, İstanbul.

Lai, Y.J. \& T.Y. Liu \& C.L. Hwang (1994), “TOPSIS for MCDM”, European Journal of Operational Research, 76, 486-500.

Özateşler, M. (1998), Iktisadi Planlama Teorisi ve Genel Üretim Modeli, Anadolu Matbaacılık, İzmir. 
Özdemir, H. (1997), “Siyasal Tarih 1960-1980”, içinde: Türkiye Tarihi 4, Çağdaş Türkiye 19081980, Cem Yayınevi, İstanbul.

Özüerman, T. (1996), “Türkiye'nin Sosyal ve Siyasal Gelişme Seyri İçinde Siyasal Partiler”, DEÜ İBF Dergisi, 11(1), İzmir.

Sönmez, S. (2003), “Türk İktisat Politikalarında Çıpa: Dış Borçlanma”, içinde: İktisat Üzerine Yazılar 2: İktisadi Kalkınma Kriz ve İstikrar Oktar Türel'e Armağan, Derleyen: Fikret Şenses, Erinç Yeldan ve Ahmet H. Köse, İletişim Yayınları, İstanbul.

Strom, K. (1985), "Party Goals and Government Performance in Parliamentary Democracies", The American Political Science Review, 79(3), 738-754.

Şanlısoy, S. (2007), "Ekonomi-Politika Etkileşiminin Süreç Politikası Açısından Analizi: Türkiye Örneği”, Yayınlanmamış Doktora Tezi, Dokuz Eylül Üniversitesi Sosyal Bilimler Enstitüsü, İzmir.

Telatar, F. (2000), "Makro Ekonomik Performans İndekslerine Göre Hükümetler Arası Sıralamalar 1950-1996”, İktisat-Işletme-Finans, 175, 55-69.

Türkiye İstatistik Kurumu (2014), Ístatistik Göstergeler (Statistical Indicators) 1923-2013, Türkiye İstatistik Kurumu Matbaas1, Ankara.

Tzeng, G.H. \& J.J. Huang (2011), Multiple Attribute Decision Making, Methods and Application, CRC Press Taylor \& Francis Group.

Yaralığlu, K. (2010), Karar Verme Yöntemleri, Detay Yayıncılık, Ankara.

Yeldan, E. (2001), Küreselleşme Sürecinde Türkiye Ekonomisi, İletişim Yayınc1lı, İstanbul.

Yeldan, E. (2008), “Kriz Türkiye’yi Nasıl Etkileyecek”, Ekonomi Politik, Ekim.

Yıldırım, O. (2004), “Türk Bankacılık Sektöründe Yaşanan Finansal Krizler (1980-2002), Íktisat Dergisi, 453, İstanbul.

Yüksel, İ. \& M. Dağdeviren (2007), "Using the Analytic Network Process (ANP) in a Swot Analysis-A Case Study for a Textile Firm”, Information Sciences, 177(16), 3364-3382.

<https://www.tbmm.gov.tr/hukumetler/HP19.htm>, 24.06.2015.

$<$ https://evds.tcmb.gov.tr>, 22.06.2015.

<https://www.muhasebat.gov.tr>, 22.06.2015.

$<$ https://www.hazine.gov.tr>, 23.06.2015.

<http://www.kalkinma.gov.tr/Pages/index.aspx>, 24.06.2015. 
Şanlısoy, S. \& M. Çetin (2016), “Türkiye Ekonomisinde Hükümetlerin Ekonomik Performanslarının TOPSIS Yöntemi İle Ölçülmesi”, Sosyoekonomi, Vol. 24(28), 65-83.

EK: 1

Hükümetlere Göre Ekonomik Performans Göstergeleri

\begin{tabular}{|c|c|c|c|c|c|c|c|c|c|}
\hline Hükümetler & $\begin{array}{l}\text { Ekonomi } \\
\text { Politikası }\end{array}$ & Yillar & $\begin{array}{l}\text { Büyüme } \\
\text { (1968SF) }\end{array}$ & İşsizlik & $\begin{array}{l}\text { Enflasyon } \\
\text { (TÜFE: } \\
1968=100)\end{array}$ & $\begin{array}{c}\text { Faiz oranı } \\
\text { (K1sa Vadeli } \\
\text { Reeskont Faizi) }\end{array}$ & $\begin{array}{c}\text { Net } \\
\text { (Kamu) } \\
\text { Dış Borç } \\
\text { Stoku }\end{array}$ & $\begin{array}{c}\text { Cari } \\
\text { Açı// } \\
\text { GSMH }\end{array}$ & $\begin{array}{l}\text { Bütçe } \\
\text { Aç̧ı̆1/ } \\
\text { GSMH }\end{array}$ \\
\hline \multirow{10}{*}{$\begin{array}{c}\text { Demokrat Parti } \\
(22.05 .1950-27.05 .1960)\end{array}$} & \multirow{12}{*}{ 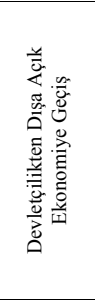 } & 1950 & 9,4 & 4,18 & $-4,4$ & 4 & 11,2 & 1,44 & 1,18 \\
\hline & & 1951 & 12,8 & 5,08 & 0,2 & 4 & $-3,2$ & 2,26 & $-0,48$ \\
\hline & & 1952 & 11,9 & 5,96 & 5,1 & 3 & 9,7 & 4,14 & $-0,47$ \\
\hline & & 1953 & 11,3 & 6,53 & 3,8 & 3 & $-8,5$ & 2,94 & 0,18 \\
\hline & & 1954 & $-3,0$ & 6,89 & 9,5 & 3 & 13 & 3,11 & 0,74 \\
\hline & & 1955 & 7,9 & 7,29 & 12,2 & 3 & 13,8 & 2,59 & 0,28 \\
\hline & & 1956 & 3,2 & 7,77 & 9,9 & 4,5 & 21,4 & 0,95 & 0,63 \\
\hline & & 1957 & 7,8 & 8,24 & 11,9 & 4,5 & 2,4 & 0,61 & 0,14 \\
\hline & & 1958 & 4,5 & 8,66 & 15,8 & 4,5 & $-0,9$ & 0,51 & $-0,05$ \\
\hline & & 1959 & 4,1 & 9,11 & 24,4 & 4,5 & 14,8 & 0,93 & $-0,25$ \\
\hline \multirow{2}{*}{$\begin{array}{c}\text { Askeri Hükümet } \\
(27.05 .1960-20.11 .1961)\end{array}$} & & 1960 & 3,4 & 9,56 & 5,2 & 4,5 & 14,11 & 1,41 & 0,09 \\
\hline & & 1961 & 2,0 & 9,56 & 1,6 & 4,5 & 9,5 & 3,10 & $-0,47$ \\
\hline CHP/AP (20.10.1961-25.6.1962) & \multirow{15}{*}{ 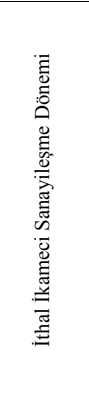 } & 1962 & 6,2 & 10,10 & 3,4 & 4,5 & 19,8 & 3,80 & $-0,17$ \\
\hline CHP/YTP/CKMP (25.06.1962- 25.12.1963) & & 1963 & 9,7 & 10,70 & 7,9 & 7,5 & $-9,97$ & 4,06 & $-0,25$ \\
\hline CHP $(25.12 .1963-20.02 .1965)$ & & 1964 & 4,1 & 9,83 & 1,2 & 7,5 & 38,24 & 1,39 & 0,86 \\
\hline \multirow{6}{*}{$\begin{array}{c}\text { Adalet Partisi } \\
(20.02 .1965-26.03 .1971)\end{array}$} & & 1965 & 3,1 & 8,98 & 5,8 & 7,5 & 7,9 & 0,92 & 0,80 \\
\hline & & 1966 & 12,0 & 8,23 & 5,7 & 7,5 & 9,87 & 1,63 & 0,10 \\
\hline & & 1967 & 4,2 & 7,22 & 8,3 & 7,5 & 12,87 & 1,03 & $-0,23$ \\
\hline & & 1968 & 6,7 & 5,95 & 3,7 & 7,5 & 18,21 & 1,24 & 0,53 \\
\hline & & 1969 & 4,1 & 5,7 & 7,8 & 7,5 & 12,21 & 1,09 & 1,28 \\
\hline & & 1970 & 3,2 & 5,5 & 8,1 & 9,0 & 11,44 & 0,90 & $-0,14$ \\
\hline \multirow{3}{*}{$\begin{array}{c}\text { MBK (26.03.1971-22.05.1972) } \\
\text { Geçici Hükümet (22.05.1972-26.01.1974) }\end{array}$} & & 1971 & 5,6 & 6,4 & 16,5 & 9,0 & 15,32 & 0,63 & 3,29 \\
\hline & & 1972 & 7,4 & 6,8 & 13,7 & 9,0 & 3,85 & 0,04 & 0,15 \\
\hline & & 1973 & 3,3 & 6,3 & 16 & 8,75 & 14,23 & $-1,73$ & 0,71 \\
\hline $\begin{array}{c}\text { CHP/MSP (26.01-17.11.1974) } \\
\text { Geçici Hükümet (17.11.1974-31.03.1975) }\end{array}$ & & 1974 & 5,6 & 6,8 & 18,6 & 8,75 & 8,07 & 1,88 & 0,92 \\
\hline I. Milliyetçi Cephe Hükümeti & & 1975 & 7,2 & 7,3 & 19,8 & 9,0 & 11,75 & 3,47 & 0,23 \\
\hline (31.03.1975-21.06.1977) & & 1976 & 10,5 & 7,6 & 16,4 & 9,0 & 28,45 & 3,78 & 0,59 \\
\hline CHP (21.06-21.07.1977) & \multirow{4}{*}{ 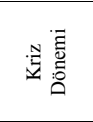 } & 1977 & 3,4 & 9 & 28 & 9,0 & 9,41 & 5,13 & 4,62 \\
\hline II. Milliyetçi Cephe Hükümeti & & 1978 & 1,5 & 10 & 47,2 & 10,0 & 43,16 & 1,89 & 1,85 \\
\hline $\begin{array}{c}(21.07 .1977-05.01 .1978) \\
\text { CHP (05.01.1978-12.11.1979) }\end{array}$ & & 1979 & $-0,6$ & 10,1 & 56,8 & 10,75 & 52,6 & 1,73 & 2,74 \\
\hline AP (12.11.1979-12.09.1980) & & 1980 & $-2,4$ & 8,9 & 115,6 & 26,0 & 30,17 & 4,98 & 3,59 \\
\hline \multirow{3}{*}{ Askeri Hükümet } & \multirow{8}{*}{ 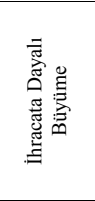 } & 1981 & 4,9 & 8,3 & 33,9 & 30,25 & 11,57 & 2,71 & 1,47 \\
\hline & & 1982 & 3,6 & 7,3 & 31,4 & 31,5 & 14,39 & 1,48 & 1,63 \\
\hline & & 1983 & 5,0 & 7,2 & 48,4 & 48,5 & 15,66 & 3,18 & 1,90 \\
\hline \multirow{8}{*}{$\begin{array}{c}\text { Anavatan Partisi } \\
(13.12 .1983-20.11 .1991)\end{array}$} & & 1984 & 6,7 & 7,9 & 45 & 52,0 & 1,4 & 2,43 & 2,77 \\
\hline & & 1985 & 4,2 & 7,8 & 34,6 & 52,0 & 20,17 & 1,51 & 1,85 \\
\hline & & 1986 & 7,0 & 7,3 & 38,9 & 48,0 & 23,46 & 1,95 & 2,94 \\
\hline & & 1987 & 9,5 & 8,1 & 75,4 & 45,0 & 27,99 & 0,94 & 4,01 \\
\hline & & 1988 & 2,1 & 8,4 & 63,3 & 54,0 & 2,33 & $-1,76$ & 3,64 \\
\hline & \multirow{14}{*}{ 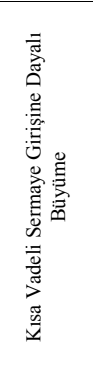 } & 1989 & 0,3 & 8,6 & 60,3 & 54,0 & 1,7 & $-0,89$ & 4,40 \\
\hline & & 1990 & 9,3 & 8 & 66 & 45,0 & 9,64 & 1,74 & 4,10 \\
\hline & & 1991 & 0,9 & 8,2 & 70,1 & 48,0 & 2,81 & $-0,17$ & 7,36 \\
\hline DYP/SHP (20.11.1991-16.05.1993) & & 1992 & 6,0 & 8,5 & 66,1 & 48,0 & 1,62 & 0,62 & 6,07 \\
\hline SHP (16.05-25.06.1993) & & 1993 & 8,0 & 8,9 & 106,3 & 48,0 & 7,94 & 3,60 & 9,79 \\
\hline DYP/SHP (25.06.93-5.11.95) & & 1994 & $-5,5$ & 8,6 & 93,6 & 55,0 & 12,53 & $-1,99$ & 3,9 \\
\hline $\begin{array}{c}\text { DYP (05- 30.11. 1995) } \\
\text { DYP/CHP (30.11.95-6.3.96) }\end{array}$ & & 1995 & 7,2 & 7,6 & 80,4 & 50,0 & 4,03 & 1,38 & 4,1 \\
\hline ANAP/DYP (06.03-28.06.1996) & & 1996 & 7,0 & 6,6 & 85,7 & 50,0 & 3,17 & 1,33 & 8,3 \\
\hline RP/DYP (28.06.1996-30.06.1997) & & 1997 & 7,5 & 6,8 & 84,6 & 67,0 & $-3,60$ & 1,37 & 7,6 \\
\hline ANAP/DSP/DTP (30.06.1997-11.01.1999) & & 1998 & 3,1 & 6,9 & 64,9 & 67,0 & 4,03 & $-0,96$ & 7,1 \\
\hline DSP $(11.01-28.05 .1999)$ & & 1999 & $-3,4$ & 7,7 & 54,9 & 60,0 & 1,53 & 0,73 & 11,6 \\
\hline \multirow{3}{*}{$\begin{array}{c}\text { DSP/MHP/ANAP } \\
(28.05 .1999-18.11 .2002)\end{array}$} & & 2000 & 6,8 & 6,5 & 54,4 & 60,0 & 17,15 & 4,91 & 10,2 \\
\hline & & 2001 & $-5,7$ & 8,4 & 45 & 60,0 & 12,36 & $-2,33$ & 16,5 \\
\hline & & 2002 & 6,2 & 10,3 & 25,3 & 55,0 & 21,52 & 0,99 & 14,4 \\
\hline
\end{tabular}


Şanlısoy, S. \& M. Çetin (2016), “Türkiye Ekonomisinde Hükümetlerin Ekonomik

Performanslarının TOPSIS Yöntemi İle Ölçülmesi”, Sosyoekonomi, Vol. 24(28), 65-83.

Adalet ve Kalkınma Partis

(18.11.2002-07.06.2015)

\begin{tabular}{|c|c|c|c|c|c|c|c|c|}
\hline \multirow{13}{*}{ 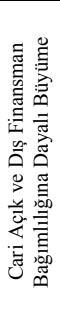 } & 2003 & 5,3 & 10,5 & 10,6 & 43,0 & 9,65 & 3,4 & 11,4 \\
\hline & 2004 & 9,4 & 10,3 & 8,2 & 38,0 & 1,43 & 5,2 & 7,09 \\
\hline & 2005 & 8,4 & 10,3 & 9,5 & 23,0 & $-12,16$ & 6,3 & 1,41 \\
\hline & 2006 & 6,9 & 9,9 & 9,65 & 27,0 & 2,19 & 7,8 & 0,61 \\
\hline & 2007 & 4,7 & 9,2 & 8,3 & 25,0 & 2,36 & 5,9 & 1,62 \\
\hline & 2008 & 0,7 & 10,0 & 10,06 & 25,0 & 3,41 & 5,7 & 1,83 \\
\hline & 2009 & $-4,8$ & 13,1 & 6,5 & 15,0 & 4,62 & 2,3 & 5,53 \\
\hline & 2010 & 9,2 & 11,1 & 6,4 & 14,0 & 4,14 & 6,5 & 4,58 \\
\hline & 2011 & 8,8 & 9,1 & 10,4 & 17,0 & 2,9 & 10,5 & 2,61 \\
\hline & 2012 & 2,1 & 8,4 & 6,1 & 13,5 & 7,24 & 6,2 & 1,52 \\
\hline & 2013 & 4,2 & 9,0 & 7,4 & 10,25 & 9,02 & 7,9 & 2,16 \\
\hline & 2014 & 2,9 & 9,9 & 8,1 & 9,0 & 4,36 & 6,4 & 1,93 \\
\hline & $2015^{*}$ & 4,0 & 10,6 & 9,9 & 9,0 & $-6,5$ & 7,0 & 1,13 \\
\hline
\end{tabular}

Kaynak: Türkiye İstatistik Kurumu (2014), İstatistik Göstergeler (Statistical Indicators) 1923-2013, Türkiye

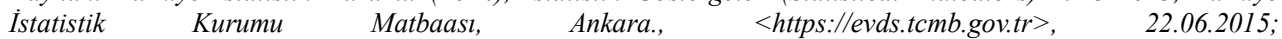
$<$ https://www.tbmm.gov.tr/hukumetler/HP19.htm>, 24.06.2015; <https://www.muhasebat.gov.tr>, 22.06.2015; $<$ https://www.hazine.gov.tr>, 23.06.2015; <http://www.kalkinma.gov.tr/Pages/index.aspx>, 24.06.2015.

EK: 2

Kriter Ağırlıkları Çerçevesinde Hükümetlerin Puanları

\begin{tabular}{|c|c|c|c|c|c|c|}
\hline \multirow{2}{*}{ Sira } & \multicolumn{2}{|c|}{ ANP } & \multicolumn{2}{|c|}{ Eşit Ağırlık } & \multicolumn{2}{|c|}{ Kirschen vd. } \\
\hline & Hükümet & Puan & Hükümet & Puan & Hükümet & \begin{tabular}{|l|} 
Puan \\
\end{tabular} \\
\hline 1 & CHP/YTP/CKMP & 0,923741 & CHP/YTP/CKMP & 0,957937 & CHP/YTP/CKMP & 0,964851 \\
\hline 2 & DP1 & 0,873350 & DP1 & 0,904822 & DP1 & 0,834871 \\
\hline 3 & AKP1 & 0,799487 & CHP-AP & 0,794301 & AKP1 & 0,775386 \\
\hline 4 & AP1 & 0,796201 & AKP1 & 0,784676 & CHP-MSP & 0,731914 \\
\hline 5 & DP2 & 0,788742 & I. MC & 0,781514 & CHP-AP & 0,728910 \\
\hline 6 & CHP-MSP & 0,780801 & DP2 & 0,767466 & DP2 & 0,718809 \\
\hline 7 & CHP-AP & 0,778811 & AP1 & 0,756891 & AP1 & 0,717084 \\
\hline 8 & ASK2 & 0,772585 & CHP-MSP & 0,721447 & DP3 & 0,710672 \\
\hline 9 & AKP3 & 0,768524 & ASK2 & 0,714441 & AKP3 & 0,705760 \\
\hline 10 & DP3 & 0,766185 & ANAP1 & 0,657869 & ASK2 & 0,704995 \\
\hline 11 & AKP2 & 0,758521 & DP3 & 0,653255 & AKP2 & 0,698373 \\
\hline 12 & AP2 & 0,753485 & CHP1 & 0,636396 & I. MC & 0,685610 \\
\hline 13 & ASK1 & 0,749926 & AKP2 & 0,620453 & AP2 & 0,654376 \\
\hline 14 & I. MC & 0,736851 & AKP3 & 0,618372 & ASK1 & 0,646652 \\
\hline 15 & CHP1 & 0,647182 & AP2 & 0,609838 & DYP RP & 0,633422 \\
\hline 16 & ASK3 & 0,643670 & ASK1 & 0,595178 & ASK3 & 0,597136 \\
\hline 17 & ANAP1 & 0,590514 & ASK3 & 0,594272 & ANAP2 & 0,580246 \\
\hline 18 & ANAP2 & 0,534860 & DYP RP & 0,587149 & ANAP1 & 0,573084 \\
\hline 19 & ANAP-DSP-DTP & 0,510038 & ANAP2 & 0,460989 & DYP Koalisyonları & 0,558791 \\
\hline 20 & DSP-ANAP-MHP & 0,502744 & DYP Koalisyonlar1 & 0,450381 & ANAP-DSP-DTP & 0,546298 \\
\hline 21 & DYP RP & 0,496239 & ANAP-DSP-DTP & 0,443272 & CHP1 & 0,491769 \\
\hline 22 & II. MC & 0,482770 & II. MC & 0,435524 & DSP-ANAP-MHP & 0,474665 \\
\hline 23 & DYP Koalisyonları & 0,451254 & DSP-ANAP-MHP & 0,390998 & II. MC & 0,378001 \\
\hline 24 & CHP2 & 0,404365 & CHP2 & 0,332747 & AP3 & 0,310226 \\
\hline 25 & AP3 & 0,267272 & AP3 & 0,169813 & CHP2 & 0,304551 \\
\hline
\end{tabular}


Şanlısoy, S. \& M. Çetin (2016), “Türkiye Ekonomisinde Hükümetlerin Ekonomik Performanslarının TOPSIS Yöntemi İle Ölçülmesi”, Sosyoekonomi, Vol. 24(28), 65-83. 